IZA DP No. 5082

Assessing the Impact of Incomes Policy: The Italian Experience

Francesco Pastore

July 2010 


\title{
Assessing the Impact of Incomes Policy: The Italian Experience
}

\author{
Francesco Pastore \\ Seconda Università di Napoli \\ and IZA
}

Discussion Paper No. 5082

July 2010

IZA

P.O. Box 7240

53072 Bonn

Germany

Phone: +49-228-3894-0

Fax: +49-228-3894-180

E-mail: iza@iza.org

\begin{abstract}
Any opinions expressed here are those of the author(s) and not those of IZA. Research published in this series may include views on policy, but the institute itself takes no institutional policy positions.

The Institute for the Study of Labor (IZA) in Bonn is a local and virtual international research center and a place of communication between science, politics and business. IZA is an independent nonprofit organization supported by Deutsche Post Foundation. The center is associated with the University of Bonn and offers a stimulating research environment through its international network, workshops and conferences, data service, project support, research visits and doctoral program. IZA engages in (i) original and internationally competitive research in all fields of labor economics, (ii) development of policy concepts, and (iii) dissemination of research results and concepts to the interested public.
\end{abstract}

IZA Discussion Papers often represent preliminary work and are circulated to encourage discussion. Citation of such a paper should account for its provisional character. A revised version may be available directly from the author. 


\section{ABSTRACT}

\section{Assessing the Impact of Incomes Policy: The Italian Experience ${ }^{*}$}

The Saint Valentine's decree (1984) and the ensuing hard fought referendum (1985), which reduced the automatisms of scala mobile, started a process of redefinition of wage fixing in Italy, which culminated with the final abolition of scala mobile (1992) and the approval of Protocollo d'intesa (1993). Since then, following New Corporatist principles, a national system of centralised wage bargaining (concertazione) and the so-called "institutional indexation" have governed the determination of wages. This paper aims to assess the impact of such incomes policy agreements on the long and short run equilibrium relationship between real wages, labour productivity and unemployment. Different time series econometric tools confirm that incomes policy has altered the relationship between real wages and productivity, generating not only a permanent downward impact on prices, but also on real wages. In a sense, incomes policy has caused a new form of (upward) wage rigidity. Interestingly, no impact of incomes policy on the weak relationship between real wages and unemployment is detected. The analysis calls for a careful revision of the 1993 Protocol aimed at: a) better protecting the purchasing power of real wages without losing control on inflation; b) introducing growth generating mechanisms.

JEL Classification: C22, E12, E25, E64, E65

Keywords: New Keynesian macroeconomic theory, neo-corporatism, models of industrial relations, Phillips Curve, incomes policy, centralised wage bargaining, macroeconomic policy evaluation, income distribution, cointegration analysis, structural break testing, scala mobile, Protocollo d'intesa, Italy

Corresponding author:

Francesco Pastore

Seconda Università di Napoli

Faculty of Law

Via Mazzocchi, 5

81055 - Santa Maria Capua Vetere (CE)

Italy

E-mail: francesco.pastore@unina2.it

\footnotetext{
* The author wishes to thank Arturo Palomba for providing excellent research assistance and for having contributed to drafting the sections 2 and 3 . In addition, he also wishes to thank Nicola Acocella, Floro Ernesto Caroleo, Elisabetta Marzano, Andrew Newell, Erasmo Papagni, Paolo Sestito, Leonello Tronti and two anonymous referees for some useful suggestions. This notwithstanding, the usual disclaimer applies.
} 


\section{Introduction}

Italy has successfully implemented dramatic disinflation from the two-digit levels of the late 1970s and early 1980s down to almost zero in the early 1990s and from then on. Of course, disinflation has been the consequence of a complex policy mix, including, in addition to incomes policy also more rigorous monetary policy and public debt stabilisation. The former, essentially a wage fixing mechanism, has been an important (though neglected in the literature) component of the policy mix. In fact, while in the 1970s money growth, also through public debt expansion, contributed to inflation, nonetheless, the engine of it was a wage-price spiral, exacerbated by scala mobile, the mechanism of wage indexation to price inflation. It was introduced in 1945 in the manufacturing sector and was generalized to all sectors of the economy in 1975.

As detailed in Section 1, arguably incomes policy started in 1984 with the Saint Valentine's decree, confirmed by a hard fought referendum in 1985. They weakened the automatisms implicit in scala mobile. An intermediate, key step towards the introduction of the new regime of wage fixing was the definitive abolition of scala mobile in 1992. The Protocollo d'intesa of 1993 (the Protocol since now) was the climax. It put an end to the traditional dramatic social conflict of the 1960s and the 1970s, when terrorism of opposite political factions brought the country in a dramatic social and political situation. It started instead the so-called concertazione between trade unions, entrepreneurial organizations and the government around a given inflation target. The Protocol substituted the automatic indexation of scala mobile, with a mechanism of "institutional indexation": in other words, workers regain any loss in purchasing power due to emerging differences between actual and target inflation only at the time when national contracts are renewed. However, this implies a loss of the purchasing power of wages for quite a lot of time, the time that is necessary to freeze out the dynamics of prices. In other words, disinflation is achieved through (real) wage reductions.

Figure 1 shows the evolution of wage and consumer price inflation over the last about forty years. The main dates that will be objet of investigation are marked with a dashed line. Scala mobile had its momentum in a period of exceptionally high inflation, 
when also due to indexation and a strong union power, wage growth almost systematically overcame consumer price growth. Instead, in the recent low inflation regime, price changes seem to anticipate wage changes, causing sometimes wages to lag behind and, therefore, losing their purchasing power. This is especially true in the early 1990s.

\section{[Figure 1 about here]}

Understanding the impact of wage policy on inflation and, as predicted by new Keynesian theory, on unemployment is of paramount importance. Almost two decades of application in one of the world leading economies are an important testing ground also to verify theoretical predictions about the policy. This notwithstanding, little research has been carried out so far on this issue and in particular on the crucial years after the introduction of the Euro. This paper aims to contribute to fill in the gap of the existing literature.

The paper applies different tools of time series analysis to study the impact of incomes policy on the relationship between real wages, labour productivity and unemployment. The main assumption of the empirical analysis is that, as hypothesized, among others, in Calmfors and Driffill (1988) and tested in Newell and Symons (1987), by introducing a centralized mechanism of wage fixing, incomes policy reduces the sensitivity of real wages to productivity growth, at least in the short run. This makes real wages fall down to their market clearing level, allowing corporatist countries to reach the same result in terms of employment as in countries where bargaining is decentralised at the firm level. In the case of Italy, Pastore (1998) attempted to test the impact of incomes policy in the aftermath of the signature of the Protocol using for the first time cointegration analysis. He found that the policy of de-indexation started in 1984 was in fact able, on the one hand, to reduce the degree of correlation between real wages and productivity in the long run, causing a (possibly) permanent reduction in the former, while, on the other hand, increasing the speed at which real wages adjust to productivity gains in the short run. In fact, by reducing the impact of inflation on real wages, incomes policy makes them adjust more quickly to any disequilibrium in the long-run relationship with labour productivity. Costantini and de Nardis (2007) update the analysis using quarterly data relative to the years 1981-2006 and find the existence of a regime shift in the real wage equation in 1994. They attribute this shift to changes 
in the system of wage formation and acceleration in the use of temporary work arrangements.

This paper provides further empirical evidence on annual data covering a longer period (1970-2008). Annual data allows us also studying the possible impact of a number of other variables in the short run equilibrium. After testing that all variables are integrated of order one, this study analyses the stability of incomes distribution and finds that the share of wages over total national income has dramatically shrank in the years after the introduction of the Agreements by about 10 percentage points. This is an important factor behind slow economic growth. In addition, the years 1993-1994 are endogenously detected by way of the Gregory and Hansen (1996) procedure as years of regime change in the parameters of the real wage equation.

Last, but not least, as noted above, based on New Keynesian theories (Tarantelli, 1986a; 1986b; Bean, Layard and Nickell, 1986; and, for a textbook explanation, Carlin and Soskice, 2005), by reducing real wages incomes policy was expected to reduce unemployment. In fact, this is not a direct effect, but an indirect one, which happens through the supposed increased competitiveness of the economy in world markets. The implicit assumption is that a reduction in real wages is able to increase export to such an extent that it should outweigh the reduction in internal demand. It is beyond the aims of this paper to study the determinants of unemployment. It is a fact that after 1993 there has been a clear trend of increasing employment and shrinking unemployment. What we find is indirect confirmation of a changed link between real wages and unemployment. In fact, the long- and the short-run elasticity of real wages to changes in the unemployment rate switches from positive to statistically insignificant in the afterProtocol period.

The outline of this paper is as follows. Section one provides a critical reconstruction of the institutional evolution of the process of aggregate wage determination. Section two shortly surveys the theoretical and empirical literature on incomes policy and their possible impact on real wages, productivity and unemployment. Section three introduces the data adopted in this paper. Section four presents the results of empirical analysis. Some summary remarks close the paper. 


\section{The institutional context}

Scala mobile was introduced in Italy in December 1945 to protect the purchasing power of salaries, wages and pensions in the manufacturing sector from any sudden increase in the inflation rate. At the beginning, the automatic indexation had a quarterly frequency. Renewal of national contracts claimed increases in real wages to improve workers' economic and social conditions. In 1975, a historical tripartite agreement between Confindustria (national association of entrepreneurs) and the three major trade unions, namely CGIL, CISL and UIL extended the system to all other industries. In addition, the frequency of wage increases became monthly ${ }^{1}$.

Soon, though, Modigliani and Padoa Schioppa (1977) blamed the perverse effects of the new scala mobile. They claimed that by making wage indexation automatic and more frequent, scala mobile had become itself a specific cause of inflation ${ }^{2}$. In the following years, Tarantelli (1986b) tried to convince politicians, business men and trade union leaders of the need to stop the "price rush" suggesting to link wage growth to target rather than to actual inflation ${ }^{3}$.

Incomes policy started indeed already in 1984 with the Saint Valentine's decree, confirmed by a hard fought referendum in 1985. The head of the government, Bettino Craxi, cut four points of indexation converting in law an agreement between Confindustria and two major trade unions, CISL and UIL. Since then, a number of laws progressively withheld scala mobile.

An intermediate, key step towards the introduction of what can be considered a completely new regime of wage fixing was the ultimate abolition of scala mobile by a tripartite agreement in 1992 on "Incomes policy, inflation and the labour cost", promoted by the head of the government, Giuliano Amato. It established also that all workers should receive a fixed $0.7 \%$ wage increase as partial compensation for inflation until December 1993. The impact of this agreement was clearly very muscular. It

\footnotetext{
${ }^{1}$ For more accurate reconstructions of the historical background, see, among others, Pastore (1997), Fabiani et al. (1998), Baccaro (2000) and the contributions in Acocella and Leoni (2007).

${ }^{2}$ For an in-depth assessment of the actual impact of indexation on wage and price inflation during the period 1963-'85, see Destefanis (1995).

${ }^{3}$ On the 27th of March 1985, brigate rosse, a terrorist organization loosely inspired by communist ideals, killed Ezio Tarantelli, a scholar of Franco Modigliani and the main theoretician of incomes policy in Italy. However, their coward attack could not prevent Tarantelli's thought to play a decisive role still today.
} 
certainly contributed to maintain price stability despite the subsequent dramatic devaluation of the Italian currency (lira) in September 1993.

The 1992 Agreement was an essential pre-condition for incomes policy, representing the switch from a conflictualist to a cooperative approach to income distribution. In principle, it considered bargaining as a way to keep the purchasing power of wages and promote a fairer social distribution of productivity growth.

The Protocollo d'intesa (Protocol since now) of July 1993, promoted by the head of the Government of the time, Carlo Azeglio Ciampi, was the climax ${ }^{4}$. The agreement institutionalized concertazione and formalized collective bargaining introducing a "tax based incomes policy”. It also introduced firm level Rappresentanze Sindacali Unitarie (Trade Union Representative Units) with the aim to supervise local agreements and obtain that they obliged to the targets defined by collective agreements.

The Protocol aimed to fight back “stagflation” by implementing price growth' control. As Tarantelli (1986b) theorized, wages must be considered a national level variable, and be compatible with the aim of containing inflation and, therefore, promoting monetary stabilization and growth. Price stability should be considered a public good essential for a fairer income distribution and increased international competitiveness. Based on this theoretical framework, protecting real wages and employment should be the main trade unions' objective. Overall, the Protocol had three main aims: 1) an inflation rate in line with the EU average; 2) a reduction in public deficit in line with the EU standards; 3) monetary stability.

In principle, the new system foresees two bargaining levels, of which level one is the industry level bargaining. The wage level is renewed every two years, while the normative part of the contract, regarding the general conditions of labour, are renewed every four years. Wage increases should be in line with inflation targets as defined in national tripartite agreements with the participation of the government, trade unions and entrepreneurial organizations. Level two is the firm' level bargaining.

The Protocol introduced what Sylos Labini called "institutional indexation": in other words, workers regain any difference between actual and target inflation only

\footnotetext{
${ }^{4}$ Interestingly, the Agreements of the early 1990s were signed without strikes or protests, in a completely new climate of industrial relations. Unions showed a remarkable sense of responsibility, assuming inflation and unemployment as an integral part of their objective function, together with the guarantee of the interests of employed workers.
} 
when national contracts are renewed, namely after two years. This implies that wages bear the cost of any unexpected inflation via a reduction in purchasing power. In fact, institutional indexation has typically involved: a) a systematic positive differential between actual and target inflation; b) an increased length of collective labour contracts; c) a systematic delay in the renewal of labour contracts; d) and only partial indexation to price inflation.

Unfortunately, several important parts of the Protocol were left unexecuted: a) firm level bargaining and the related need to introduce incentives to productivity growth ${ }^{5}$; b) the promise to trade unions to contribute to the management of social services and other aspects of the organisation of the welfare state; c) the need to control also the evolution of other types of incomes, especially of rents.

In 2007, a government led by Romano Prodi signed a new Protocol on Welfare which introduced a number of challenging novelties that were never implemented, though, because a new government, which came into power few months after the signature of the Agreement, withdrew it.

In February 2009, the Minister of Labour, Maurizio Sacconi, and two major trade unions, namely CISL and UIL, signed a new agreement to allow a decentralized system of wage bargaining. Tronti (2010) argues that it is a way to achieve a stronger link between wages, labour productivity and profits by allowing firm level bargaining to take into account cases where labour productivity growth was greater (lower) than the national level. In turn, this should work as an incentive for productivity growth at a firm level ${ }^{6}$.

Since the Protocol approval, two major changes have affected income distribution. First, the well-known rigidities of the Italian labour market have progressively reduced, thanks to two-tier labour market reforms. In 1997, the Treu law introduced a new discipline of temporary labour contracts and a number of other so-called "atypical"

\footnotetext{
${ }^{5}$ As one of the anonymous referees points out, the very high weight of small and medium-sized firms typical of the Italian industrial structure has prevented effective working of a "second bargaining level".

${ }^{6}$ CGIL, the trade union with the largest number of members, did not sign the Agreement. Analysis of the 2009 Agreement is beyond the aims of this paper. Acocella and Leoni (2010) articulate a lucid assessment of the possible impact of the 2009 Agreement on real wages and productivity growth, reckoning that the former will be slightly negative and the latter unimportant. The authors also provide a number of policy proposals to favour labour productivity growth and therefore cause long-lasting increases in the purchasing power of wages.
} 
contracts. The law removed most of the constraints that until then had made such contracts inconvenient for firms and workers, while introducing, in the meantime, a number of new constraints to their inappropriate use. Law n. 30 of 2003 - so-called "Biagi law" ${ }^{7}$ - with Roberto Maroni as Ministry of Labour introduced a number of new types of atypical labour contracts ${ }^{8}$, in fact, allowing firms to partly getting around previous constraints included in Treu law. Second, wages have been compressed due to the need to stabilise massive public debt. The highest tax revenues have drawn asymmetrically on salaries, wages and pensions, on the one hand, and on the incomes of self-employed, on the other hand, since the former cannot recur to tax evasion and elusion, which are massive in Italy ${ }^{9}$.

\section{Motivation}

The Protocol has caused a regime change in the process of wage determination in Italy that allows the prevalence of bargaining on automatic indexation, according to the so-called neo-corporatist approach to income policy as defined, among others, in Meade (1982), Layard and Nickell (1986) and Tarantelli (1986b).

Are there testable hypotheses that can be drawn from the historical reconstruction of the previous section? First, several dates are in principle candidate to detect a possible regime switch in the process of wage determination: 1984 (Saint Valentine's decree), 1992 (abolition of Scala Mobile); 1993 (the Protocol); 1997 (Treu Law); 2003 (Biagi law). Comparing these dates would imply asking whether it was the "de-indexation”, incomes policy or two-tier reforms to cause disinflation. The previous analysis suggests

\footnotetext{
${ }^{7}$ On 19th of March 2002 brigate rosse killed Marco Biagi, a labour law scholar at the University of Modena and a consultant of the government.

${ }^{8}$ It is far beyond the aims of this paper to provide a full assessment of these laws. In short, it could be noted that, although named after Biagi, law n. 30 / 2003 implements only part of the heritage of Biagi, as discussed in his White book. The law, in fact, does not include but a minor part of the section of Biagi' proposal aimed at introducing some income guarantees for temporary workers during unemployment spells and after retirement. Nonetheless, it improved the condition of project workers by substituting the old co.co.co. with the new co.co.pro. contract and including some social security provisions in favour of project workers.

${ }^{9}$ According to the KRLS Network of Business Ethics, Italy is the country with the highest tax evasion in Europe. In the first ten months of 2009, 51.2\% of taxable income (about $€ 389$ billions) has gone undeclared. This amounts to a tax evasion of $€ 144$ billions per year. In fact, this implies that the tax rate of actual tax payer is not the official $43 \%$, but over $50 \%$.
} 
that the way itself of implementing incomes policy, and especially the new mechanism of institutional indexation, has caused a strong reduction in real wages.

The second issue is whether incomes policy has had any effect on unemployment as predicted by neo-Keynesian theories. In other words, the analysis should address the issue whether the unemployment reduction of the 2000s was a consequence of incomes policy or of labour market liberalisation. Studying the determinants of unemployment is not an aim of this paper, but it will ask whether the policy was able to change the elasticity of real wages to unemployment.

Answering these questions, in turn, implies asking: a) whether incomes policy has generated greater coordination in the process of wage fixing in national collective contracts; b) and, therefore, whether there has been greater co-movement of wages, prices, labour productivity and unemployment in the aggregate. In fact, this paper focuses only on the latter question, assuming, in fact, that b) is a consequence of a).

\section{Literature review}

\subsection{Theoretical predictions and early empirical evidence}

Meade (1982) re-launched incomes policy as a means to fight stagflation and reestablish the role of expansionary fiscal policy as a tool to fight unemployment. In other words, he proposed a neo-Keynesian alternative to the monetarist approach to disinflation. He suggests that if the government can achieve monetary stability through tripartite agreements with trade unions and entrepreneurial organisations, then aggregate demand management can be used again to increase employment. Moreover, once price stability is achieved, the economy is able to catch the opportunities of the expansionary phase of the business cycle. This is the essence of the neo-corporatist approach to disinflation. Interestingly, Meade added that to avoid the distortions that centralised wage bargaining might cause in the process of resources' allocation, wage fixing should contain some degree of de-centralisation. Real wage growth should equal labour productivity growth in every firm / sector to achieve the greatest impact of wage fixing on inflation and, indirectly, also on income and employment growth. 
Tarantelli (1986a; 1986b) applies the theory of public goods to the problem of price stability analysing the effects of incomes policy in countries with a centralized level of bargaining and in decentralized systems. In the latter, there is a high risk that individuals and groups of workers try to avoid paying the cost of wage and price stability by implementing a free riding behaviour. Small unions, for instance, do not accept lower wage requests and, by doing so, their workers benefit of higher relative wages without an increase in the average inflation rate. The more decentralized is the system, the greater is the number of agents who will try to free ride. The cumulative effect is higher inflation, higher unemployment and lower average real wages. This result is not Pareto-optimal. A more centralized system of industrial relations carries with it a lower risk of wage free riding and greater price stability. Decentralized countries are less credible and more easily blocked by small trade unions. According to Tarantelli, centralization and decentralization are not alternative models. They might reinforce each other. In countries with a centralized system of wage fixing, incomes policy is a solution for the macro regulation of inflation and unemployment. However, once reached the macro-level agreement, trade unions' market power can define the plant level rules. Achieving this marriage of opposites is very difficult , though, as the case of Italy proves.

Calmfors and Driffil (1988, p. 15) investigate the effects of the degree of centralization of wage setting on macroeconomic performance. They study centralized systems, such as Germany, Belgium and the Nordic countries; decentralized systems with real wage flexibility, such as Canada and the USA; and countries with an intermediate degree of centralization. They find that low unemployment is obtained either because of heavy centralization, which is conducive to real wage restraints, or because of far-reaching decentralization, which is characterized by real wage flexibility. Conversely, in countries with an intermediate degree of centralization, the unemployment rate is higher. This is the so-called hump-shaped curve of wage bargaining. The ratio is that, in corporatist countries, large trade unions recognize their market power and take into account both the inflationary and unemployment effect of wage increases. Conversely, unions operating only at a firm level have little market power and cannot affect the market clearing level of wages. In intermediate cases, 
unions exert a market power but do not consider the macroeconomic implications of their actions.

Bean, Layard and Nickell (1986) estimated wage equations using time series data relative to 18 OECD countries. The differences in the estimated wage and employment equations depend both on demand factors and on real wage differentials. Especially in the European Union, a reduction in the aggregate demand is one of the major causes of unemployment rising. Second, supply-side factors play a significant role in wage equations influencing the size of unemployment. Third, structural differences in labour markets are related to the institutional context and bargaining level of a country. In more corporatist countries wage adjustment is faster.

Newell and Symons (1987) focus on the impact of incomes policy on unemployment and show that corporatism produces a wage outcome lower than it would have been in decentralized countries. They analyze the wage equations of 5 countries (Sweden, Germany, Britain, Japan and the USA), trying to associate the average level of unemployment to the specific country market institutions. They find that in centralized countries incomes policy increases the sensitivity of real wages to unemployment. They argue that reducing real wages is a way to prevent unemployment growth in periods of economic downturn. They have in mind an aggregate labour demand curve: lower real wages imply lower labour costs for firms and therefore more employment. In some neo-keynesian formulations of incomes policy, including Tarantelli (1986a), the reduction of unemployment is achieved through increased international competitiveness.

Dolado and Jimeno (1997), use a structural VAR methodology in five variables (output, employment, wage, price and unemployment) associating different causes of unemployment in Spain with shocks of different nature. They study the impact of five structural shocks (aggregate demand, wage-push, price-push, productivity and labour supply shocks) with impulse-response functions. In particular, they find that wage shocks become the most important source of unemployment.

\subsection{Previous research on Italy}


Little research has been done to assess the impact of incomes policy on the Phillips curve in Italy. Pastore (1998) developed, in the context of cointegration analysis, some intuitions of Newell and Symons (1987). They assumed that incomes policy tends to reduce the sensitivity of real wages to labour productivity growth and to re-establish the negative sign of the elasticity of real wages to unemployment. Pastore (1998) applied the Engle and Granger (1987) procedure using annual data from 1951 to 1995. An advantage of this approach is that it provides a direct measure of wage flexibility, defined as the coefficient of residuals of the long run equation, used as a regressor in the short run equation. The error correction mechanism, sometimes called the feedback mechanism, measures the speed of adjustment of real wages to their long-term equilibrium value.

The analysis suggests stability of income distribution in the long run, but also a tendency of wages to overcome labour productivity during part of the period. To test for the impact of incomes policy, in the short run, the author interacts the residuals from the long run estimates with a dummy equal to one for the period 1985-1995, when indexation was gradually withdrawn. He finds that the speed of adjustment of real wages to their equilibrium path increased in the same period by about 20 percent. Finally, there seems to be no change in the relationship between real wages and unemployment, suggesting either that other forms of labour market flexibility, such as numerical flexibility, were necessary or that more time was needed to see the restoration of a competitive principle in the process of wage determination.

Using the same data, Golinelli (1998) finds a stable relationship between variations in real wages and the unemployment rate in the short run using an error correction model characterized be a non linear correction of the error.

Fabiani et al. (2001) provide further evidence that incomes policy agreements were conducive to a period of wage moderation. In the long term, instead, the absence of indexation and the new two-year bargaining system have increased the inertia of nominal wages. Applying a methodology similar to Dolado and Jimeno (1997), the authors investigate the causes of unemployment in a small structural VAR. In the short term, "wage push" shocks do not seem to have contributed to the worsening of unemployment; on the contrary, productivity shocks play a significant role in explaining 
unemployment movements. In the long run they found the absence of the effects of these non demand factors.

Destefanis, Mastromatteo and Verga (2005) analyse the effects of the 1992 and 1993 agreements on inflation for two-digit industry real wage equations. They find that the target rate of inflation has an impact on the formation of expected inflation over the period 1992-'96, but they find a negligible effect of the agreements on the relationship between labour productivity and real wages.

Costantini and de Nardis (2007) focus on the impact of labour market reforms on real wage equations using quarterly observations from 1981 to 2006. They use the Gregory and Hansen (1996) residual based test for cointegration to find any structural break in the long run relationship between real wages, labour productivity and unemployment. They actually find that 1994 is a year of regime shift, which they interpret as a switch from high to low equilibrium unemployment. They compare parameter elasticities before and after the break and find that the responsiveness of real wages to the unemployment rate substantially increased from -0.136 to -0.262 . In addition, the elasticity of real wages to labour productivity goes near to one-to-one in the long run.

It is also worth mentioning that Devicienti et al. (2008) also find the re-emergence of a wage curve effect - meaning a negative coefficient of monthly wages with respect to local unemployment - in the post-1993 period, pointing to increased wage flexibility which they attribute to the new regime of industrial relations.

\section{The data}

The analysis is based on annual data from 1970 to 2008. This is an important difference with respect to Costantini and De Nardis (2006), who use quarterly data relative to 1980-2006. Taking annual data for a longer period may indeed be an advantage in two ways: (a) as Pierse and Snell (1995) note, in cointegration analysis, having more years is at a premium vis-à-vis having a larger number of higher frequency data; (b) it is easier to find annual data relative to other variables such as trade union density, the gap between consumer prices and value added deflator, the gap between 
import prices and value added deflator, and some measure of the tax wedge ${ }^{10}$. The possible impact of these variables on the short-run equilibrium real wage is tested.

The variables' definition is standard. The real wage (WR) is measured as the ratio of per capita nominal wage and the consumer prices index $(C P I)$. The former is obtained, in turn, as a ratio of the earnings of wage employees $(R L D)$, nominal values, over the number of wage employees in thousands of units $(U L D)$. The consumer price index CPI is the ratio of the nominal family expenditure $(C N)$, at current prices, and the real family expenditure $(C R)$, values at constant prices. Labour productivity $(L P)$ is given by the ratio between real GDP (GDPR), at constant prices of the base year 2000, and total employment (ULT), in thousands of total labour units. The unemployment rate $(u)$ is the ratio of the number of the unemployed $(U N)$ and the labour force $(L F)$, values in thousands of total units of labour. Trade union density (TUD) is the share of wage employees that are trade union members. The gap between consumer price index and value added deflator is measured as $(C P I-P)$. The gap between import prices and value added deflator is $(P M-P)$. The ratio of total labour taxes (TLT) over the earnings of wage employees is a measure of the tax wedge on labour (TWEDGE)Tables A.1 in the Appendix provides a full definition and source of all the variables used in the analysis. They are taken from the National Account as provided by ISTAT, except for the unemployment rate and trade union density, which are drawn from the OECD data base. Variables at constant prices are expressed in terms of the prices of the base year 2000. All variables are in natural logarithms. Percentage changes are computed by means of logarithmic differences.

Before implementing cointegration analysis, we enquire variables for their order of integration. First, panel (a) and (b) of Figure 2 plot the variables at levels and at first differences, respectively. Note that in panel (a) the unemployment rate is measured on the right side due to strong differences. Real wages tend to become flat starting from the early 1990s, with the growth rate fluctuating around zero and accumulating several negative values since then. The percentage change of the unemployment rate tends to be negative starting from the late 1990s, causing an important reduction from $11.7 \%$ in 1998 down to $6.1 \%$ in 2007. Low labour productivity growth from the early 1990s suggests that two-tier labour market reforms have contributed to employment growth, at

\footnotetext{
${ }^{10}$ I thank one of the referees for this remark.
} 
least in part. In fact, according to ISTAT data, about one out of three new jobs created over the years from 1997 to 2008 has been temporary. An additional component has been due to the legalisation of irregular migrants.

\section{[Figure 2 about here]}

Table 1 reports the ADF test statistics for the variables of interest at levels and at first-differences $^{11}$. The critical values are provided in the last row of the table. The test statistics in Panel (a) in correspondence to the highest values of the reported information criteria (in bold) can never reject the null of non-stationarity, while those selected in Panel (b) do reject the null, confirming that the variables are I(1).

\section{[Table 1 about here]}

As a robustness check, we implement also the Phillips and Perron test, which is more sensitive to the presence of structural breaks in the data, and the DF-GLS, which has more power than the previous tests. In addition, we provide also results of the Zivot and Andrews (1992) test in the case when shifts in both the intercept and trend are allowed. This procedure estimates the test statistics for each observation, assuming the existence of possible structural breaks in the data, and provides the minimum value of these statistics $^{12}$. All the tests, reported in Table 2, confirm that the variables are I(1), not rejecting the null of a unit root when the estimates refer to levels and rejecting it when they refer to first-differences. The table adds also tests for the other variables, such as trade union density, the wedge, and PPM and the CPIGAP.

[Table 2 about here]

\section{Results}

Once checked that all variables are I(1), we proceed by estimating the so-called WPYE model (Alogoskoufis and Smith, 1991). It implies testing the null of "nocointegration” between real wages and labour productivity. In other words, we aim to verify whether the relationship WPYE, obtained as (wages - prices - output + employment), is stable in the long run with the following coefficients: $(+1,-1,-1,+1)$.

\footnotetext{
${ }^{11}$ Since OLS detects the presence of a constant and / or a trend in all variables, either at levels or at differences, we report the tests with intercept and trend.

${ }^{12}$ For shortness' sake, we do not discuss in detail such tests. A more in-depth discussion can be found in recent handbooks of time series analysis.
} 
This would imply that real wages and labour productivity cointegrate with coefficients $(1,-1)$ and therefore that the share of labour income over output is stable over time. If the series WPYE contains a unit root, the underlying variables do not cointegrate; vice versa, if the series does not contain a unit root, then the variables cointegrate. In other words, cointegration implies testing the variable WPYE for the presence of a unit root.

Figure 3 plots the WPYE series before transformation in logarithms, so that the figures can be read directly as the labour share of GDP. Clearly, a dramatic downward shift in the series from about $68 \%$ down to a low of $57 \%$ happens in the early 1990 s. This is a dramatic loss, with potentially important effects also on economic growth, considering the higher propensity to consume of labour incomes. It appears particularly strong in per capita terms, if one considers that, after a brawny reduction in employment and corresponding increase in unemployment due to the 1991 recession, starting from 1995 the employment rate has increased and the unemployment rate has reduced until recently ${ }^{13}$.

\section{[Figure 3 about here]}

Overall, this finding is suggestive of the hypothesis that real wages have grown at a much slower pace than labour productivity in recent years ${ }^{14}$. Nonetheless, it is worth noticing that apart from the years 1991-'95, when it undergoes a dramatic reduction, the labour share is stable. In other words, real wages and labour productivity seem to have the expected unitary coefficients both until 1990 and from 1995 on. This is either evidence of a non-stationarity or of a structural break. In any case, unit root tests might tend to suggest non-stationarity.

In fact, results reported in Table 3 from different unit root tests on WPYE provide evidence of a structural break in the data. The ADF test, based on a model with a constant, but no trend (the labour share of national income is expected to be untrended $)^{15}$ clearly cannot reject the null of non-stationarity. A similar conclusion is reached using a Phillips and Perron (1988) and the DF-GLS test. The Zivot and

\footnotetext{
${ }^{13}$ Blanchard (2006, Figure 14a) finds something similar in the case of France. He notes that the labour share, which had gone up by five percentage points from 1970 to 1981, then went down by 12 percentage points from 1980 to the early 2000s; it has remained roughly at that level since.

${ }^{14}$ This depends also on the fact that the Protocol does not foresee mechanisms to equalise real wage growth and productivity growth (see Acocella and Leoni, 2010; and Tronti, 2010).

${ }^{15}$ Adding a trend to the test tends to return stationarity in some cases.
} 
Andrews (1992) test cannot reject the null of a unit root at the $1 \%$, but at the $5 \%$ significance level. Figure 4 reproduces the results of the ZA test for the share of wage employment over GDP. It clearly shows that in 1994 the test statistics undergoes a dramatic reduction.

\section{[Table 3 and Figure 4 about here]}

This is overwhelming evidence of the fact that the labour share has shrunk over the considered period. However, the question arises as to the causes of the emergence of a structural break. Is it because of a shift down in the series, which has left unaltered the one-to-one relationship between real wages and labour productivity? Or is it because of a change in the relationship between these two variables? A first answer to these questions comes from observation of the scatter of real wages and labour productivity in Figure 5. It shows that the relationship between the two variables looks one-to-one only until the early 1990s, when real wages stop growing in presence of (very slow) labour productivity growth.

\section{[Figure 5 about here]}

To control for the presence of a structural break in the data, we add a dummy variable (D1993), which equals one in the years after 1993, to a DF type of test. The dummy is statistically significant with a coefficient that suggests a ceteris paribus reduction in the log of the labour share on national income of about $5 \%$ in the period of interest. Interestingly, the t-statistics of the lagged labour share, computed using Newey-West HAC standard errors, now equals -4.5, suggesting that the series is stationary once controlling for the presence of a shift. This finding might be taken as an indirect test that incomes policy has changed the process of wage determination.

The results of the Engle and Granger procedure relative to the three variables of interest, including the unemployment rate, provide evidence which concurs to reinforce previous findings ${ }^{16}$. The long-run estimates do not generate stationary residuals, as expected in case of cointegration, but the corresponding cointegration test on the residuals increases dramatically when the dummy D1993 is included. Table 4 reports the results of estimates of the long-run relationship and of the cointegration test, namely the ADF test on the residuals of each long run equation. Both the estimate without

\footnotetext{
${ }^{16}$ Unreported results of Johansen cointegration tests (available on request) consistently point to the existence of only one cointegrating vector among the variables under consideration.
} 
(model 1) and with the income policy dummy (model 2) are reported. Model (3) interacts the policy dummy with each determinant of real wages. It is apparent that only in the case of model (2) and (3) the test statistics selected based on the highest value of the AIC and SBC information criteria rejects the null of non-stationary residuals, and only at the $10 \%$ significance level.

\section{[Table 4 about here]}

Interestingly, in model (2) of Table 4 the elasticity of real wages to labour productivity is higher. This finding is reinforced in model (3), where clear signs of a regime shift are detected. In other words, once controlling for the downward bias of real wages in the period after de-indexation, real wages reach an elasticity of almost one. The sign of the unemployment rate is positive and statistically significant in model (1). In model (2) and (3), the unemployment rate is not statistically significant. This is already an important change in the (perverse) relationship between real wages and unemployment typical of the previous period already noted in Costantini and De Nardis (2006), who find the re-emergence of a negative sign, and Devicienti et al. (2008), who see a resurrection of the wage curve. Figure 6 shows that the Phillips curve, expressed here in terms of real (not nominal) wage changes, is highly unstable. Disinflation has shifted it back to the left allowing the country to move on what Costantini and De Nardis (op. cit.) call a low unemployment regime.

\section{[Figure 6 about here]}

A test similar to that in model (3) of Table 4 consists of estimating two different equations in the pre- and post-reform period. Table 5 reports first step estimates of the Engle and Granger procedure run on the two sub-samples relative to the pre- and postreform period. The small number of observations available suggests taking these estimates with the due caveats, since the super-consistency property of estimates involving cointegrating relationships does not apply in the case of small samples (Stock, 1987). Nonetheless, it is worth perhaps reporting these findings. While in the pre-reform period there was a one-to-one relationship between real wages and labour productivity, instead after the reform there is a statistically significant negative coefficient, suggesting that institutional indexation has reduced the elasticity of real wages to productivity growth. The traditional negative correlation with the unemployment rate is reestablished in the post-reform period, although with a low elasticity. 


\section{[Table 5 about here]}

The short run estimates, reported in Table 6, are based on the residuals of models presented in Table 4. Model (1) and (2) in Table 6 are based on residuals of estimates in model (1) and (3) of Table 4, respectively. The dependent variable is the percentage rate of growth of real wages. Lagged residuals appear as a regressor together with lagged values of the dependent and independent variables as well as of other variables that might affect the short run dynamics ${ }^{17}$. In both cases, labour productivity growth and changes in the unemployment rate do not affect wage growth. Few variables are statistically significant in model (1), while the error correction mechanism is weak. The latter appears stronger in model (2), where also other regressors become statistically significant.

Next issue consists of asking whether incomes policy has affected the adjustment mechanism. Assuming that, by implementing collective agreements and, therefore, increasing the degree of centralisation of wage fixing, incomes policy should increase the speed to which real wages adapt to changes in labour productivity, then the coefficient of lagged residuals should increase in absolute value. In a sense, this would point to an increase in the degree of wage and, hence, of labour market flexibility. In a way comparison of model (1) and (2) in Table 6 already confirms this. An additional test consists of estimating the short run equation in Table 6 using the residuals for the pre- and post-transition real wage equations presented in Table 5. Two (unreported) estimates have been run. The first one includes only labour productivity and unemployment. It yields an error correction mechanism of -0.46 . When using all the regressor in Table 6 , the coefficient of the residuals equals -0.79 . The corresponding coefficients for the post-reform period equal -0.89 and -2.04 . The latter values are both higher than that found in previous research relative to older data (Pastore, 1997).

\section{[Table 6 about here]}

Overall, the previous analysis provides circumstantial evidence to suggest that incomes policy has increased the degree of labour market flexibility leading to a dramatic real wage reduction.

\footnotetext{
17 The specifications reported in the table are the result of large experimentation and have been selected based on several information criteria and other diagnostic tests, as suggested by the general-tospecific approach.
} 
A further issue is whether we can confirm that the regime change has happened after implementation of incomes policy. The Gregory and Hansen (1996, p. 101) approach can be seen as a multivariate extension of the univariate unit root ZA test used to detect the presence of structural breaks. It is used to test the null hypothesis of no cointegration against the alternative of cointegration in the presence of a regime shift. All three types of models conceived in Gregory and Hansen are considered for comparative purposes in Table 7. While the ADF statistics reject the null of unit root, the ZA statistics is less conclusive. All tests, though, detect the early 1990s as the years when the structural break takes place.

\section{[Table 7 about here]}

Table 8 provides Gregory and Hansen' types of estimates of the parameters of the Italian Phillips curve considering also different ways in which the structural break could take place. Interestingly, the parameters estimated using Gregory and Hansen are very similar to those estimated in the first step of the Engle and Granger procedure. In model (2), once controlling for the presence of a trend shift, the elasticity of real wages to labour productivity is greatly increased. Model (3) seems to detect a regime shift in the relationship between real wages and unemployment. After the break, which is endogenously found to happen in 1991, the coefficient of unemployment becomes statistically insignificant, as in model (3) of Table 4.

[Table 8 about here]

\section{Discussion and policy implications}

In a decade or so, Italy has moved from being one of the EU countries with the highest to one with the lowest inflation rate. Incomes policy has been an important component of the policy mix used to achieve disinflation. It started with the progressive abolition of scala mobile and its substitution with the so-called institutional indexation in the early 1990s. In other words, nominal wages should adjust to the gap between actual and target inflation only when national contracts are renewed, every two years, or even after more than two years in the very common case of late contract renewal.

The econometric analysis carried out in this paper shows that starting from the time of implementation of the new indexation mechanism, real wages have grown at a slower 
pace than labour productivity. It implied a dramatic reduction, by slightly less than 10 percentage points of the labour share over GDP. Different statistical tests, including the Gregory and Hansen' (1996) one, point to a regime change in the relationship between real wages, labour productivity and unemployment in the early 1990s, the time when the Protocol was implemented. Variables appear to cointegrate using the Engle and Granger procedure only when a dummy for 1993 is included in the estimates alone or interacted with other variables.

The main conclusion of this study is that incomes policy has increased the degree of labour market flexibility, meant here as the speed at which real wages turn to their longrun equilibrium value, but not the sensitivity of real wages to productivity growth. In fact, in the post-reform period, real wages tend not to follow productivity growth any more. In a sense, incomes policy has caused an unprecedented form of (upward) wage rigidity and a dramatic reduction in real terms.

This is partly in line with theoretical predictions (see Calmfors and Driffil (1988) and Newell and Symons (1987). However, it is also related to the inefficient way of working of "institutional indexation". Indexation to the gap between actual and target inflation has happened only too late and partially. In addition, the loss of purchasing power of wages has happened in a period of highest tax burden on wages to stabilise a dramatic public debt and of increasing prices of some primary goods whose weight on the budget of low income people is high after the introduction of the Euro. In turn, the real wage stagnation has most likely contributed to the recent slowdown in economic growth experienced in recent years.

The analysis has important policy implications. Above all, it is necessary to tackle the main issue at stake in this paper: new rules are necessary to avoid the progressive erosion of the purchasing power of wages due to inflation. There are different ways of doing so: a) rendering any gap between actual and expected inflation yearly and automatically; b) introducing some kind of tax penalty for any delay in the signature of national contracts; c) rendering the fiscal drag to wage employees. Other not less important policy interventions include the fight against tax evasion and an increase in the degree of competitiveness in goods markets. These interventions are key to a strategy whose aim is to increase the competitiveness (and therefore the growth prospects) of the country in the long run. 
According to Acocella and Leoni (2010), the aforementioned 2009 Agreement does not include arrangements sufficient to protect the purchasing power of wages. They forecast further wage reductions as a consequence of the implementation of this Agreement ranging from $-0.11 \%$ to $-0.67 \%$ per year. In addition, the Agreement does not include sufficient incentives to increase labour productivity which has remained stagnant for a very long time ${ }^{18}$.

\section{Concluding remarks}

The Saint Valentine's decree (1984) and the ensuing hard fought referendum (1985), which reduced the automatisms of scala mobile, started a process of redefinition of wage fixing in Italy, which culminated with the final abolition of scala mobile (1992) and the approval of Protocollo d'intesa (1993). Since then, following New Corporatist principles, a national system of centralised wage bargaining (concertazione) and the socalled "institutional indexation" have governed the determination of wages.

This paper aims to assess the impact of such incomes policy agreements on the long and short run equilibrium relationship between real wages, labour productivity and unemployment. Different time series econometric tools, including the Engle and Granger and the Gregory and Hansen procedures confirm that incomes policy has altered the relationship between real wages and productivity, generating not only a permanent downward impact on prices, but also on real wages. In a sense, incomes policy has caused a new form of (upward) wage rigidity. In addition, incomes policy has changed the elasticity of real wages to the unemployment rate from positive to statistically insignificant, mirroring the recent reduction in the unemployment rate.

The analysis also confirms theoretical expectations regarding the increased elasticity of real wages to their equilibrium value as measured by the coefficient of lagged residuals in the short run real wage equation, which has increased from -0.46 in the pre-reform to -0.79 in the post-reform period. The Zivot and Andrews (1992) unit root test on the labour share and the Gregory and Hansen (2006) cointegration tests applied to the real wage equation concur to endogenously point to the early 1990s, and especially 1994, as the year of the regime shift.

\footnotetext{
${ }^{18}$ For a more optimistic view on the 2009 agreement, see Tronti (2010).
} 
The analysis calls for a careful revision of the 1993 Protocol aimed at: a) better protecting the purchasing power of real wages without losing control on inflation; b) introducing growth generating mechanisms.

Future developments of this research will focus on disentangling the impact of incomes policy vis-à-vis other policy interventions, namely monetary policy and labour market liberalisation on prices and unemployment respectively. This is essential to prove causality. This implies also adding more variables, including trade union density, to the theoretical framework adopted in the paper. In addition, the analysis of the impact of wage policy on individual pay using disaggregated data is expected to shed new light on the actual impact of incomes policy on the link between real wages and labour productivity across industries and firms. 


\section{References}

Acocella, N. and R. Leoni (2007, eds.), Social Pacts, Employment and Growth. A Reappraisal of Ezio Tarantelli's Thought, Physica Verlag, Heidelberg.

Acocella, N. and R. Leoni (2010), "La riforma della Contrattazione: redistribuzione perversa o produzione di reddito?", forthcoming in Rivista Italiana degli economisti.

Alogoskoufis, G.S. and R. Smith (1991), "On Error Correction Models: Specification, Interpretation, Estimation”, Journal of Economic Surveys, 5(1): 97-128.

Baccaro, L. (2000), "Centralised Collective Bargaining and the Problem of "Compliance". Lessons from the Italian Experience”, Industrial and Labour Relations Review, 53(4): 579-601.

Bean, C., R. Layard, and S. Nickell (1986), "The rise in unemployment: A multi-country study", Economica, 53(210): S1-S22.

Blanchard, O. (2006), "European Unemployment: The Evolution of Facts and Ideas", Economic Policy, 21(45): 5-59.

Calmfors, L. and J. Driffill (1988) "Bargaining structure, corporatism and macroeconomic performance”, Economic Policy, 3(1): 13-61.

Carlin, W. and D. Soskice (2005), Macroeconomics. Imperfections, Institutions and Policies, Oxford University Press.

Costantini, M. and S. de Nardis (2007) "Estimates of structural Changes in the wage equation: some evidence for Italy”, ISAE Documenti di lavoro, n. 86, November.

Destefanis, S. (1995), "Aggiustamento dei salari, indicizzazione e inflazione: una analisi empirica per l'industria in senso stretto, 1963-1985", Lavoro e relazioni industriali, (3): 3-58.

Destefanis, S., G. Mastromatteo, G. Verga (2005), "Wages and monetary policy in Italy before and after the wage agreements", Rivista internazionale di scienze sociali, 113(2): 289318.

Devicienti, F. A. Maida and L. Pacelli (2008), "The Resurrection of the Italian Wage Curve", Economics Letters, 98(3): 335-341.

Dolado, J. J., J. F. Jimeno (1997), “The Causes of Spanish Unemployment: A Structural VAR Approach”, European Economic Review, 41(7): 1281-1307.

Engle, R.F. and C.W.J. Granger, (1987), "Cointegration and Error correction: Representation, Estimation, and Testing”, Econometrica, 55(2): 251-76.

Fabiani, S., A. Locarno, G. Oneto and P. Sestito (1998), "Risultati e problemi di un primo quinquennio di politica dei redditi: una prima valutazione quantitativa", Banca d'Italia, Temi di discussione, n. 329, March.

Fabiani, S., A. Locarno, G. Oneto and P. Sestito (2001), " The sources of unemployment fluctuations: an empirical application to the Italian case”, Labour Economics, 8(2): 259289.

Golinelli, R. (1998), "Fatti stilizzati e metodi econometrici «moderni»: una rivisitazione della curva di Phillips per l'Italia (1951-1996)", Rivista di Politica Economica, 14(5): 411446. 
Gregory, A.W. and B.E. Hansen (1996), "Residual-Based Tests for Cointegration in Models with Regime Shifts", Journal of Econometrics, 70(1): 99-126.

Layard R. \& Nickell S. (1986), “An Income Policy to Help the Unemployed”, Employment Institute, London.

Meade, J.E. (1982), Stagflation. Wage Fixing, Allen \& Unwin, London.

Modigliani, F. e T. Padoa Schioppa (1977), "La politica economica in una economia con salari indicizzati al 100 per cento e più", Moneta e credito, Rivista trimestrale della BNL, 30(117): 3-53.

Newell, A. and J. Symons (1987), "Corporatism, Laissez-Faire and the Rise in Unemployment", European Economic Review, 31(3): 567-601.

Pastore, F. (1997), “Controllo salariale, inflazione e disoccupazione in Italia” (1997), Novus Campus, 2(2/3): 4-22 (http://www.novuscampus.it/pdf/1997/19972302.pdf).

Pastore, F. (1998), "Le politiche salariali in una unione monetaria. Un'applicazione al caso italiano" in Schilirò D. (ed., 1998), Coordinamento della politica macroeconomica internazionale e occupazione, Intilla editore [En. Tr.: Coordination of International macroeconomic policy and employment], Messina, 199-212.

Pierse, R.G. and A.J. Snell (1995), "Temporal Aggregation and the Power of Tests for a Unit Root", Journal of Econometrics, 65(2): 333-345.

Stock, J. M. (1987), “Asynthotic Properties of the Least Square Estimators of the Cointegrating Vectors”, Econometrica, 55(5): 1035-56.

Tarantelli, E. (1986a), "The Regulation of Inflation and Unemployment", Industrial Relations, 25(1): $1-15$.

Tarantelli, E. (1986b), Economia politica del lavoro, UTET, Torino.

Tronti, L. (2007), "The July Protocol and Economic Growth: The Chance Missed", in Aceocella, N. and R. Leoni (op. cit.).

Tronti, L. (2010), "The Italian Productivity Slowdown: The Role of the Bargaining Model", forthcoming in this issue of the International Journal of Manpower.

Zivot, E. and D. W K. Andrews (1992), "Further Evidence on the Great Crash, the Oil-Price Shock, and the Unit-Root Hypothesis", Journal of Business \& Economic Statistics, 10(1): 251-70. 


\section{Appendix of Tables and Figures}

Table 1. The Dickey-Fuller test statistics for level and first-difference variables

\begin{tabular}{|c|c|c|c|c|c|c|c|c|c|}
\hline & \multicolumn{9}{|c|}{ Panel (a): Levels } \\
\hline \multirow[t]{2}{*}{ Variables } & \multicolumn{3}{|c|}{ LWR } & \multicolumn{3}{|c|}{ LPL } & \multicolumn{3}{|c|}{$\mathbf{L U}$} \\
\hline & t-stat & AIC & SBC & t-stat & AIC & SBC & t-stat & AIC & SBC \\
\hline DF & -1.89 & 96.33 & 94.04 & .14 & 93.93 & 91.64 & -1.08 & 50.53 & 48.24 \\
\hline $\mathrm{ADF}(1)$ & -1.91 & 95.52 & 92.46 & .38 & 93.18 & 90.13 & -1.54 & 50.45 & 47.40 \\
\hline $\mathrm{ADF}(2)$ & -1.96 & 94.94 & 91.12 & .58 & 92.45 & 88.64 & -.93 & 50.24 & 46.43 \\
\hline ADF (3) & -1.91 & 93.94 & 89.37 & .73 & 91.67 & 87.10 & -1.19 & 49.72 & 45.14 \\
\hline $\mathrm{ADF}(4)$ & -1.99 & 93.47 & 88.13 & 1.14 & 91.71 & 86.37 & -.83 & 48.91 & 43.58 \\
\hline \multirow[t]{2}{*}{ Critical value } & \multicolumn{9}{|c|}{-3.55} \\
\hline & \multicolumn{9}{|c|}{ Panel (b): First-differences } \\
\hline Variables & \multicolumn{3}{|c|}{ DLWR } & \multicolumn{3}{|c|}{ DLPL } & \multicolumn{3}{|c|}{ DLU } \\
\hline & t-stat & AIC & SBC & t-stat & AIC & SBC & t-stat & AIC & SBC \\
\hline DF & -5.25 & 94.57 & 92.28 & -6.14 & 94.10 & 91.81 & -5.80 & 50.15 & 47.86 \\
\hline $\mathrm{ADF}(1)$ & -3.34 & 93.82 & 90.77 & -4.59 & 93.26 & 90.20 & -5.86 & 50.75 & 47.69 \\
\hline $\mathrm{ADF}(2)$ & -2.92 & 92.86 & 89.04 & -3.88 & 92.36 & 88.54 & -3.88 & 49.89 & 46.07 \\
\hline $\mathrm{ADF}(3)$ & -2.89 & 92.14 & 87.56 & -3.75 & 91.91 & 87.33 & -3.93 & 49.49 & 44.90 \\
\hline $\mathrm{ADF}(4)$ & -3.25 & 92.34 & 87.00 & -2.43 & 91.67 & 86.33 & -3.59 & 48.58 & 43.24 \\
\hline Critical value & & & & & -3.55 & & & & \\
\hline
\end{tabular}


Table 2. PP, DF-GLS and Zivot and Andrews unit root tests

\begin{tabular}{l|c|c|c|c}
\hline & \multicolumn{4}{|c}{ Panel (a): Variables at levels } \\
\hline Variables & ADF & PP & DF-GLS & ZA \\
\hline LWR & & -2.83 & $-1.10(0)$ & $-4.57(1990)$ \\
LPL & & -0.23 & $-0.36(1)$ & $-3.63(1994)$ \\
LU & & -020 & $-1.21(1)$ & $-2.202(1986)$ \\
TUD & -0.05 & -0.72 & $-1.12(1)$ & $-5.45(1984)$ \\
TWEDGE & -1.92 & -1.97 & $-1.93(0)$ & $-3.36(1989)$ \\
PPM & -1.54 & -1.66 & $-1.55(0)$ & $-1.85(1986)$ \\
CPIGAP & -1.59 & -1.34 & $-1.40(1)$ & $-2.59(1979)$ \\
\hline Critical Values 1\% & -3.62 & -4.22 & -3.77 & -5.57 \\
\hline & & \multicolumn{2}{|c}{ Panel (b): Variables at differences } \\
\hline Variables & ADF & PP & DF-GLS & ZA \\
\hline DLWR & & $-5.97 * * *$ & $-4.45(0) * * *$ & $-6.54(1993) * * *$ \\
DLPL & & $-6.13 * * *$ & $-6.15(0) * * *$ & $-7.035(1984)^{* * *}$ \\
DLU & $-4.58 * * *$ & $-4.60(0) * * *$ & $-6.167(1988) * * *$ \\
TUD & $-3.29 * *$ & $-3.14^{* *}$ & $-2.30(0) * *$ & $-6.49(1984) * * *$ \\
TWEDGE & $-6.33^{* * *}$ & $-6.40^{* * *}$ & $-6.40(0) * * *$ & $-7.73(1998) * * *$ \\
PPM & $-5.12^{* * *}$ & $-5.07 * * *$ & $-5.18(0) * * *$ & $-5.60(1986) * * *$ \\
CPIGAP & $-3.40^{* *}$ & $-3.39 * *$ & $-3.43(0) * *$ & NO BREAK \\
\hline Critical Values 1\% & -3.62 & -4.22 & -3.77 & -5.57 \\
\hline
\end{tabular}

Notes: i) the PP is computed using the Bartlett Kernel with automatic Newey-West bandwidth selection (Newey and West 1994); ii) the DF-GLS test is computed with the number of lags chosen using the SBC criterion (between brackets); iii) the ZA represents the Zivot and Andrews (1992) test. The break date is between brackets. 
Table 3. Unit root tests for the labour share of national income

\begin{tabular}{l|c|c|c|c}
\hline Variable & ADF & PP & DF-GLS & ZA (1) \\
\hline & \multicolumn{4}{|c}{ Levels } \\
\hline WPYE & $-0.44(0)$ & -0.35 & $-0.43(0)$ & $-5.839(1994)^{* * *}$ \\
\hline & \multicolumn{4}{|c}{ First-Differences } \\
\hline WPYE & $-6.94(0)^{* * *}$ & $-6.98(1)^{* * *}$ & $-3.35^{* * *}$ & $-7.33(2001)^{* * *}$ \\
\hline Critical Values 1\% & -3.62 & -3.62 & -2.63 & $-5.57(1 \%)$ and $-5.08(5 \%)$ \\
\hline
\end{tabular}

Notes: The ADF test is computed using the SBC as an automatic selection criterion of the maximum number of lags (reported between brackets). For the other test statistics, see the note under table 2 . In addition, ZA (1) represents the case with intercept only and ZA (2) the case with intercept and trend. The null is the presence of a unit root.

Table 4. First step of the Engle and Granger procedure, overall sample

\begin{tabular}{|c|c|c|c|c|c|c|c|c|c|}
\hline Dependent variable & \multicolumn{9}{|c|}{ Real wages } \\
\hline Variables & \multicolumn{3}{|c|}{ (1) } & \multicolumn{3}{|c|}{ (2) } & \multicolumn{3}{|c|}{ (3) } \\
\hline Constant & \multicolumn{3}{|c|}{$1.076^{* * *}$} & \multicolumn{3}{|c|}{$-0.450 *$} & \multicolumn{3}{|c|}{-0.462} \\
\hline Labour productivity & \multicolumn{3}{|c|}{$0.588 * * *$} & \multicolumn{3}{|c|}{$0.801 * * *$} & \multicolumn{3}{|c|}{$0.998 * * *$} \\
\hline Unemployment rate & \multicolumn{3}{|c|}{$0.083 * * *$} & \multicolumn{3}{|c|}{$0.567 * *$} & \multicolumn{3}{|c|}{-0.032} \\
\hline D1993 & & & & \multicolumn{3}{|c|}{$-0.09 * * *$} & \multicolumn{3}{|c|}{$4.368 * * *$} \\
\hline D1993*Labour productivity & & & & & & & \multicolumn{3}{|c|}{$-1.159 * * *$} \\
\hline \multirow[t]{3}{*}{ D1993*Unemployment rate } & & & & & & & & -0.08 & \\
\hline & \multicolumn{9}{|c|}{ Cointegration test on the residuals of the above models } \\
\hline & t-stat & AIC & SBC & t-stat & t-stat & AIC & SBC & AIC & SBC \\
\hline DF & -1.81 & 87.79 & 87.03 & -3.09 & 84.61 & 83.85 & -4.75 & 99.96 & 99.20 \\
\hline ADF (1) & -2.36 & 88.50 & 86.98 & -2.65 & 83.62 & 82.09 & -3.35 & 99.36 & 97.83 \\
\hline ADF (2) & -2.47 & 87.86 & 85.57 & -2.37 & 82.62 & 80.33 & -2.70 & 98.45 & 96.16 \\
\hline ADF (3) & -2.63 & 87.33 & 84.28 & -3.13 & 83.99 & 80.94 & -2.76 & 97.80 & 94.75 \\
\hline ADF (4) & -2.92 & 87.27 & 83.45 & -4.34 & 87.17 & 83.35 & -3.58 & 99.72 & 95.90 \\
\hline $\begin{array}{l}\text { Critical value at } 5 \% \\
\text { significance level }\end{array}$ & \multicolumn{3}{|c|}{-4.00} & \multicolumn{3}{|c|}{-4.44} & \multicolumn{3}{|c|}{-5.22} \\
\hline
\end{tabular}


Table 5. First step of the Engle and Granger procedure, subsamples

\begin{tabular}{|c|c|c|c|c|c|c|}
\hline Variables & \multicolumn{3}{|c|}{ 1970-1992 } & \multicolumn{3}{|c|}{ 1993-2008 } \\
\hline Dependent variable & \multicolumn{3}{|c|}{ Real wages } & \multicolumn{3}{|c|}{ Real wages } \\
\hline Constant & \multicolumn{3}{|c|}{-0.462} & \multicolumn{3}{|c|}{$3.906 * * *$} \\
\hline Labour productivity & \multicolumn{3}{|c|}{$0.998 * * *$} & \multicolumn{3}{|c|}{-0.161} \\
\hline Unemployment rate & \multicolumn{3}{|c|}{-0.318} & \multicolumn{3}{|c|}{$-0.040 * *$} \\
\hline & \multicolumn{6}{|c|}{ Cointegration test on the residuals of the above models } \\
\hline & t-stat & AIC & $\mathrm{SBC}$ & t-stat & AIC & SBC \\
\hline $\mathrm{DF}$ & -3.36 & 49.51 & 49.06 & -5.55 & 40.20 & 40.00 \\
\hline $\operatorname{ADF}(1)$ & -2.24 & 49.04 & 48.15 & -3.74 & 39.42 & 39.02 \\
\hline $\mathrm{ADF}(2)$ & -1.75 & 48.14 & 46.81 & -3.31 & 38.78 & 38.18 \\
\hline ADF (3) & -1.84 & 47.44 & 45.66 & -3.17 & 38.45 & 37.66 \\
\hline $\operatorname{ADF}(4)$ & -2.81 & 49.65 & 47.42 & -4.05 & 39.93 & 38.93 \\
\hline Critical value & \multicolumn{3}{|c|}{-4.25} & \multicolumn{3}{|c|}{-4.61} \\
\hline
\end{tabular}

Table 6. Second step of the Engle and Granger procedure

\begin{tabular}{l|c|c}
\hline Variables & $(1)$ & $(2)$ \\
\hline Dependent variable & DLWR & DLWR \\
\hline Constant & -0.009 & -0.042 \\
D1993 & $-0.021^{* *}$ & $-0.0194^{* *}$ \\
DLP(-1) & -0.008 & -0.147 \\
DLU(-1) & -0.082 & -0.026 \\
TUD(-1) & $0.002^{*}$ & $0.002^{* *}$ \\
TWEDGE(-1) & -0.151 & 0.050 \\
PPM(-1) & -0.038 & $-0.090^{*}$ \\
DLPPM(-1) & -0.052 & $-0.087^{* * *}$ \\
CPIGAP(-1) & 0.029 & $0.435^{* * *}$ \\
DLCPIGAP(-1) & 0.000 & 0.001 \\
R(-1) & $-0.266^{* *}$ & $-0.725^{* * *}$ \\
\hline DW & 2.15 & 2.01 \\
Adj-R & 0.42 & 0.61 \\
\hline
\end{tabular}

Note: Heteroskedasticity consistent coefficient of covariance. White correction. The lagged residual in model (1) is obtained from model (1) in Table 4. That in model (2) is obtained from model (3) in Table 4.

Table 7. Gregory and Hansen (1996) cointegration tests

\begin{tabular}{llllllll}
\hline Model & \multicolumn{3}{c}{ ADF Procedure } & \multicolumn{5}{c}{ Phillips Procedure } \\
\hline & ADF & Lags & Break & ZA statistics & Break & ZT statistics & Break \\
\hline (1) Level shift & $-4.85^{* *}$ & 0 & 1994 & -26.28 & 1994 & $-4.44^{*}$ & 1994 \\
(2) Level shift with trend & $-5.09^{* *}$ & 0 & 1993 & -29.29 & 1993 & $-4.80^{*}$ & 1993 \\
(3) Regime shift & $-5.50^{* * *}$ & 0 & 1992 & -30.96 & 1991 & $-5.07^{* *}$ & 1991 \\
\hline
\end{tabular}

Note: The type of model is based on Gregory Hansen (1996, p. 103). $\mathrm{H}_{0}$ : no cointegration in the case with a structural break in the level (1), in the level and trend (2) and in the case of a regime shift (3). The critical values for the ADF and ZT statistics are at the 1 significance level: -5.13 (model 1), -5.45 (model 2) and -5.47 (model 3); at the 5\% significance level: -4.61 (model 1), 4.99 (model 2) and -4.95 (model 3). The critical value for the ZA statistics are at the $10 \%$ significance level: -36.19 (model 1), -43.22 (model 2) and -41.85 (model 3).

* means significant at $10 \%$ level; ** at $5 \%$; *** significant at $1 \%$. 
Table 8. Gregory and Hansen (1996) estimates of the real wage equation

\begin{tabular}{l|c|c|c}
\hline Variables & $(1)$ & $(2)$ & (3) \\
\hline Dependent variable & WR & WR & WR \\
\hline Constant & $-1.673^{* * *}$ & -0.400 & $2.024^{* * *}$ \\
LP & $0.524^{* * *}$ & $0.883^{* * *}$ & $0.459^{* * *}$ \\
LU & $0.145^{* * *}$ & $0.122^{* * *}$ & $0.192^{* * *}$ \\
Constant*Dbreak & 0.020 & 0.043 & 1.426 \\
Trend & & -0.006 & 0.164 \\
LPL*Dbreak & & & -0.18 \\
LU*Dbreak & & & -0.232 \\
\hline
\end{tabular}

Note: Model (1) refer to a model with a level shift; Model (2) to a model with a level shift with trend; Model (3) to a model with regime shifts (Gregory and Hansen, 1996, p. 103). The Dbreak is a dummy variable taking a value of 1 for the years after the break detected, as reported in Table 7.

* means significant at $10 \%$; $* *$ at $5 \% ; * * *$ at $1 \%$. 
Figure 1. Wage and consumer price inflation

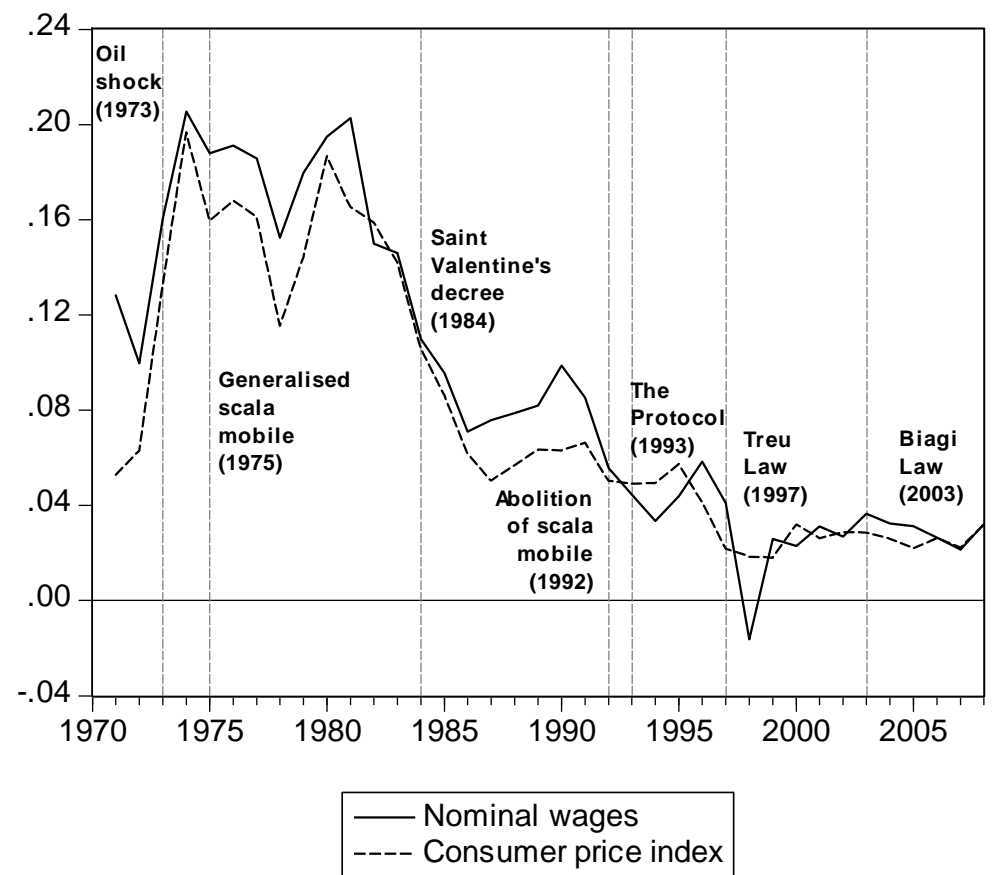


Figure 2. Real wages, labour productivity and unemployment

Panel (a): Levels

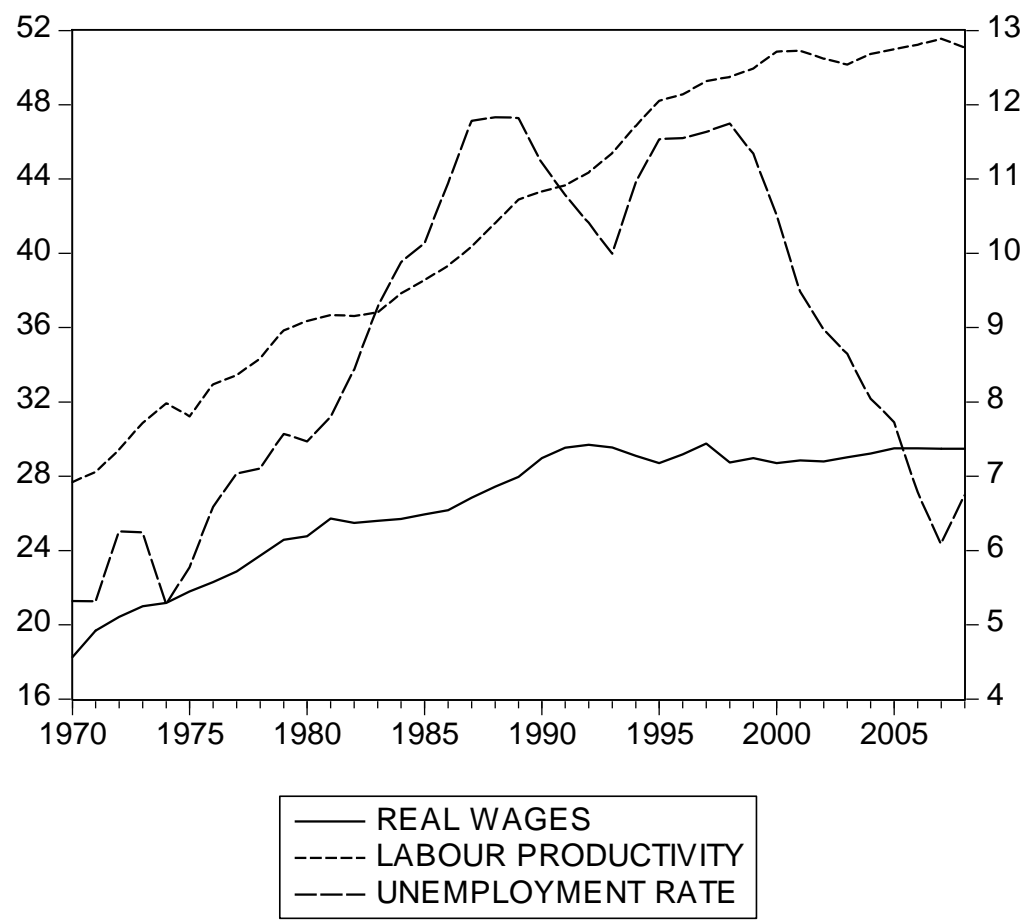

Panel (b): First-differences

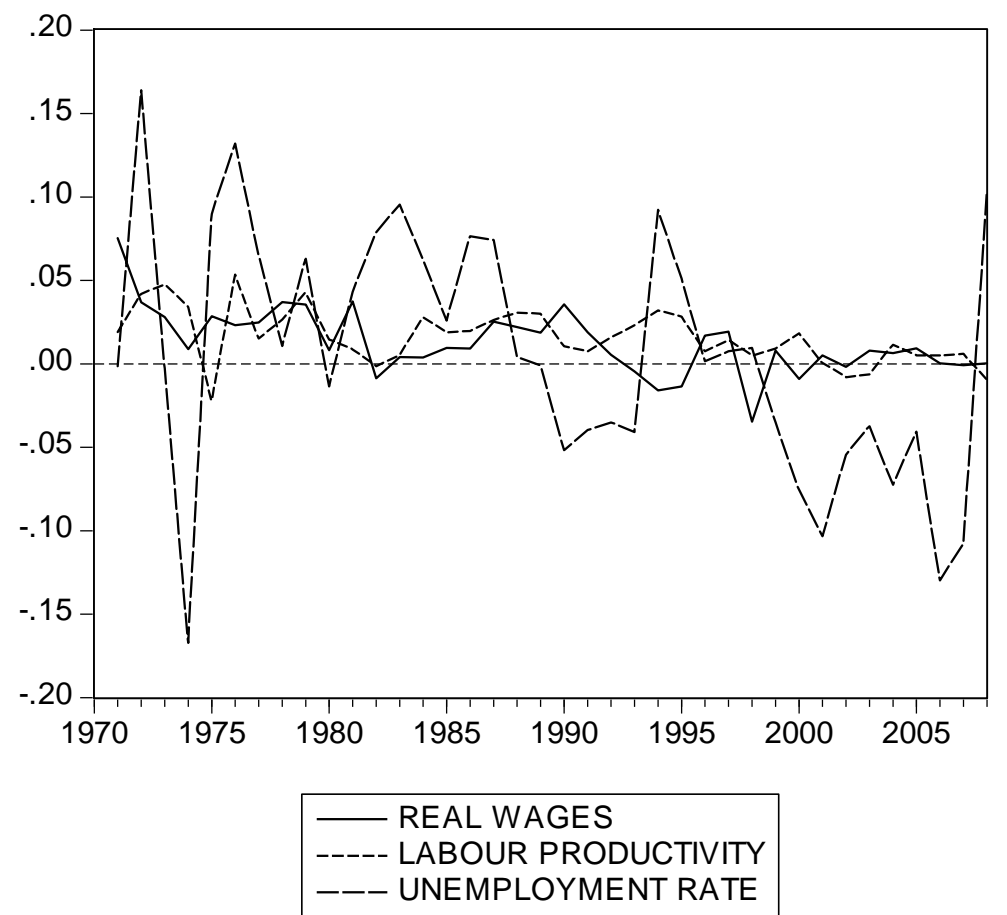

Note: In Panel (a), variables are not in natural logarithms. The level of real wages and labour productivity are measured on the left axis, whereas the unemployment rate is measured on the right axis. Panel (b) represents percentage changes as obtained by the logarithmic difference. 
Figure 3. WPYE: Share of wages in output (as a \% of GDP)

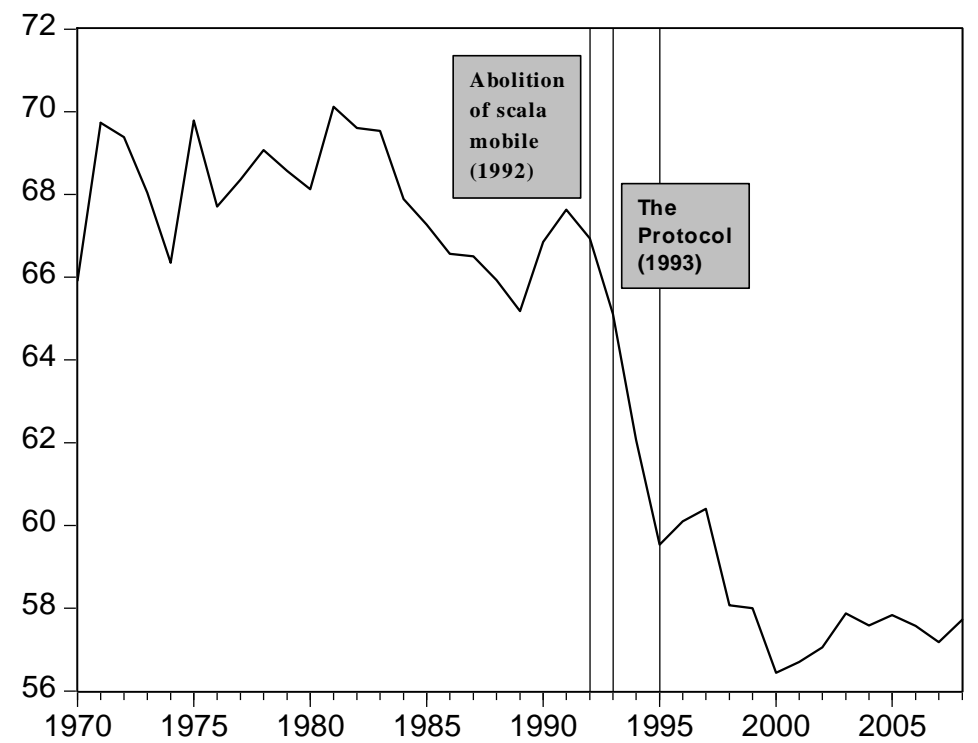

Figure 4

Zivot-Andrews test for wpye, 1976-2002

Min breakpoint at 1994

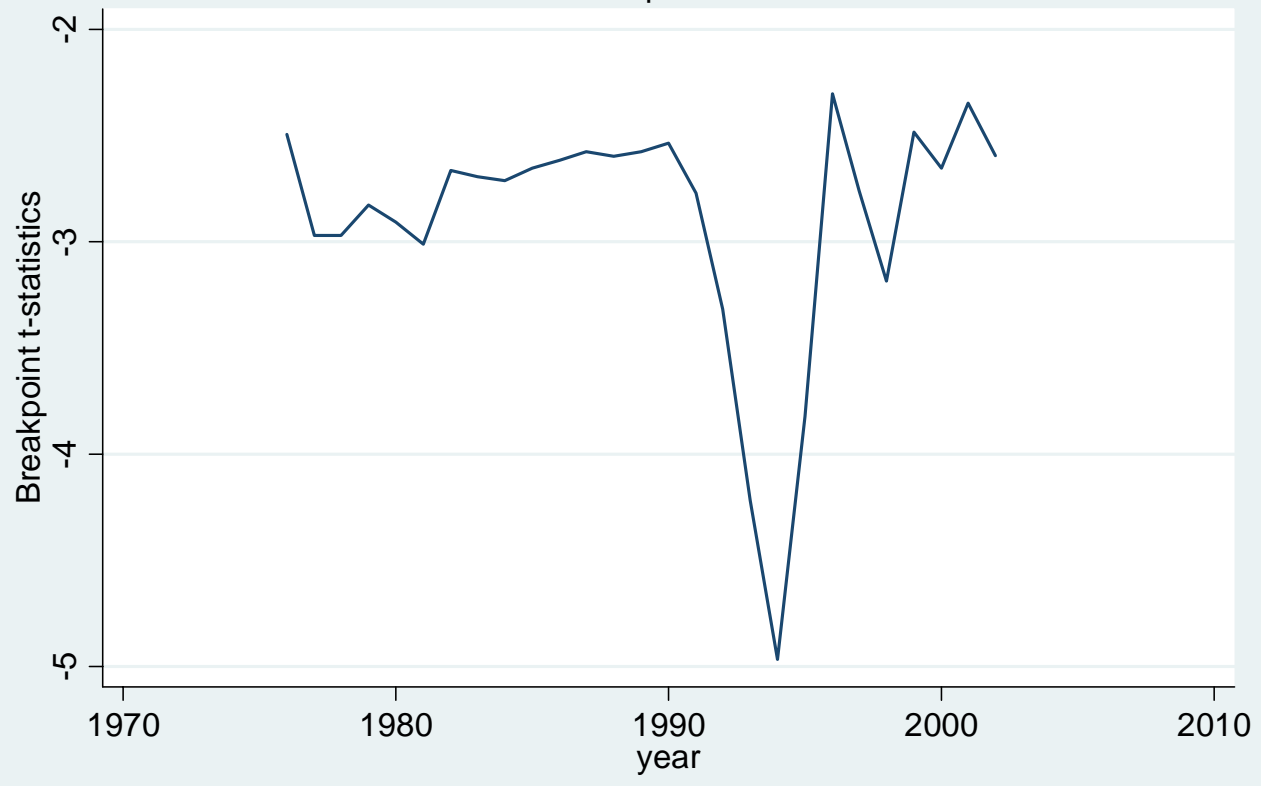

Note: Critical values equal -5.08 (5\%) and -5.57 (1\%). 
Figure 5. Scatter of real wages and labour productivity

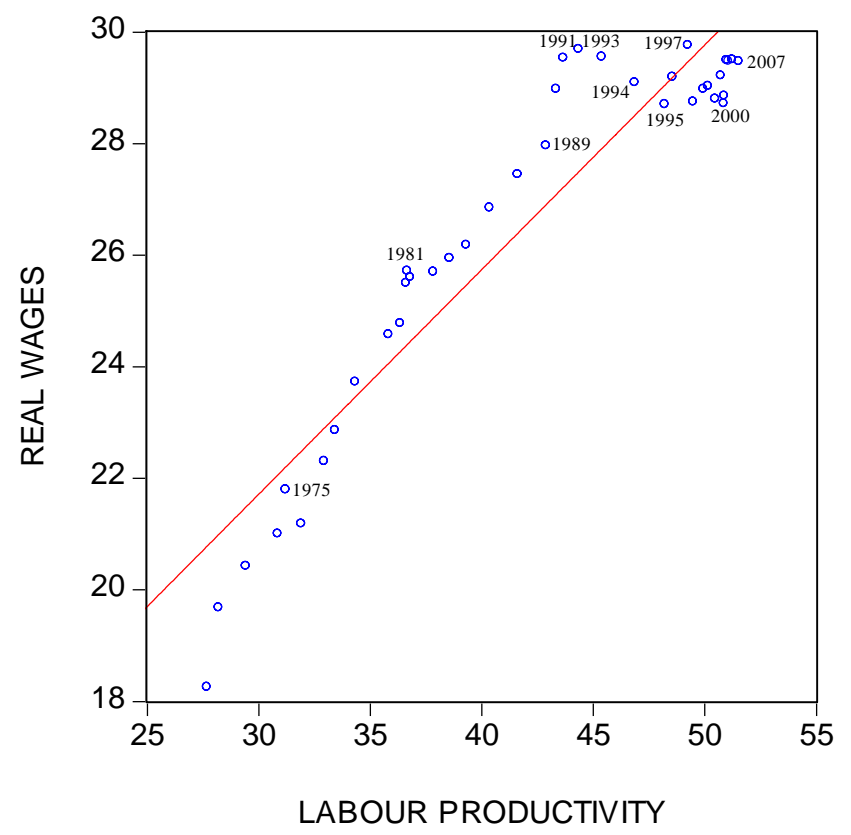

Figure 6. The (real) Phillips curve: Real wage inflation and the unemployment rate

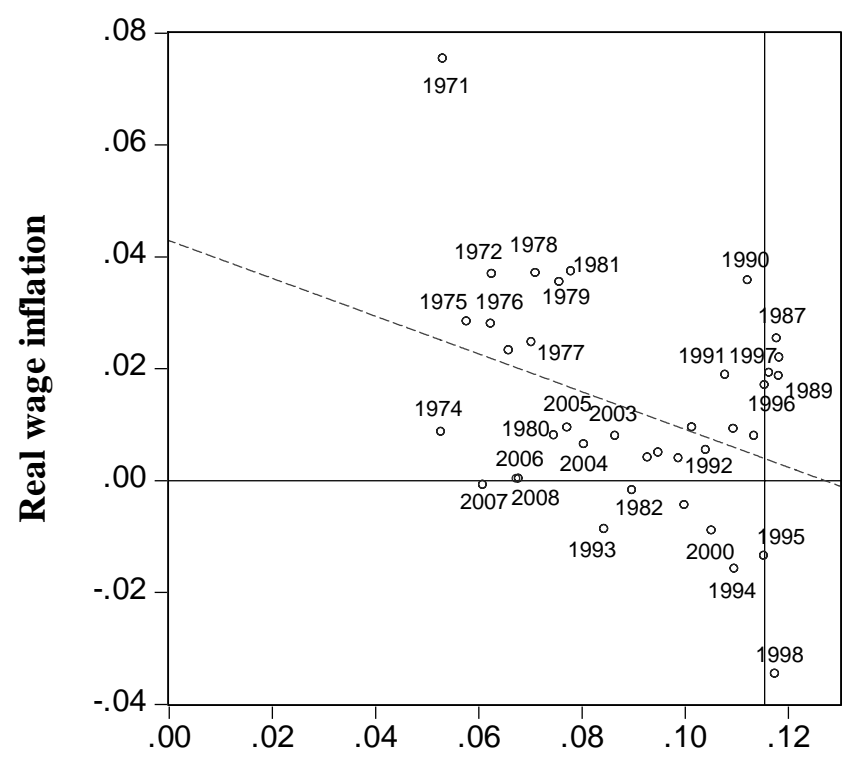

Unemploymen rate 


\section{Annex}

Table A.1. Variables definition

\begin{tabular}{|c|c|c|}
\hline Name & Description & Source \\
\hline CN & $\begin{array}{l}\text { Family expenditure, values at current prices (millions of Euros from } 1999 \text { on; } \\
\text { millions of Euros / Italian lire for earlier years). }\end{array}$ & ISTAT \\
\hline CR & $\begin{array}{l}\text { Family expenditure, values at constant prices of the base year } 2000 \text { (millions of } \\
\text { Euros from } 1999 \text { on; millions of Euros / Italian lire for earlier years). }\end{array}$ & ISTAT \\
\hline CPI & Consumer price index $=\mathrm{CN} / \mathrm{CR}$ & \\
\hline GDP & $\begin{array}{l}\text { Production at inputs' costs, values at current prices (millions of Euros from } 1999 \\
\text { on; millions of Euros / Italian lire for earlier years), total. }\end{array}$ & ISTAT \\
\hline GDPR & $\begin{array}{l}\text { Production at inputs' costs, base year } 2000 \text { (millions of Euros from } 1999 \text { on; } \\
\text { millions of Euros / Italian lire for earlier years), total. }\end{array}$ & ISTAT \\
\hline $\mathbf{P}$ & GDP deflator = GDP / GDPR & \\
\hline CPIGAP & Gap between consumer prices and value added deflator = CPI - P & \\
\hline $\mathbf{M}$ & $\begin{array}{l}\text { Import of goods and services, values at current prices (millions of Euros from } \\
1999 \text { on; millions of Euros / Italian lire for earlier years). }\end{array}$ & \\
\hline MR & $\begin{array}{l}\text { Import of goods and services, values at constant prices of the base year } 2000 \\
\text { (millions of Euros from } 1999 \text { on; millions of Euros / Italian lire for earlier years). }\end{array}$ & \\
\hline PM & Import prices = M - MR & \\
\hline PPM & Gap between import prices and value added deflator $=\mathrm{PM}-\mathrm{P}$ & \\
\hline EM & Employed, total unit of labour (in thousands). & OCSE \\
\hline UN & Unemployed, total unit of labour (in thousands). & OCSE \\
\hline $\mathbf{L F}$ & Labour force $=\mathrm{EM}+\mathrm{UN}$. & \\
\hline $\mathbf{U}$ & Unemployment rate $=(\mathrm{UN} / \mathrm{LF})$ & OCSE \\
\hline RLD & $\begin{array}{l}\text { Gross wage and salary earnings, nominal values (millions of Euros from } 1999 \text { on; } \\
\text { millions of Euros / Italian lire for earlier years) (in Italian: reddito da lavoro } \\
\text { dependente, RLD). }\end{array}$ & ISTAT \\
\hline ULD & $\begin{array}{l}\text { Number of wage and salary earners, thousands of units; so-called dependent } \\
\text { labour units (unità di lavoro dipendente). }\end{array}$ & ISTAT \\
\hline TLT & Total labour tax, social contributions to be paid by employers, current prices & \\
\hline TWEDGE & The ratio of total labour tax over gross wage and salary earnings = TLT / RLD & \\
\hline ULT & $\begin{array}{l}\text { Total employment, dependent and independent, thousands of units; so-called total } \\
\text { labour units (unità di lavoro totale). }\end{array}$ & ISTAT \\
\hline TUD & $\begin{array}{l}\text { Trade union density, ratio of wage and salary earners that are trade union } \\
\text { members divided by the total number of wage and salary earners. Data adjusted } \\
\text { for non-active and self-employed members. }\end{array}$ & OCSE \\
\hline WR & Real wage $=(($ RLD / ULD $) / C P I)$ & \\
\hline $\mathbf{L P}$ & Labour productivity = GDPR / ULT. & \\
\hline WPYE & Labour share $=[((\mathrm{RLD} / \mathrm{ULD}) / \mathrm{CPI}) /(\mathrm{GDPR} / \mathrm{ULT})] * 100$ & \\
\hline
\end{tabular}

